\title{
Occurrence of Metopism in Dry Crania of Adult Brazilians
}

\author{
Ivan do Nascimento da Silva, ${ }^{1}$ Katharina Jucá de Moraes Fernandes, ${ }^{2}$ \\ Antônio José Casado Ramalho, ${ }^{2}$ Rodrigo Freitas Monte Bispo, ${ }^{3}$ \\ Célio Fernando de Sousa Rodrigues, ${ }^{3}$ and José Aderval Aragão ${ }^{4}$
}

\author{
${ }^{1}$ Faculdade Integrada Tiradentes (FITS), Avenida Comendador Gustavo Paiva 5017, Cruz das Almas, 57038-000 Maceió, AL, Brazil \\ ${ }^{2}$ Centro Universitário (Cesmac), Rua Cônego Machado, 918 Farol, 57051-160 Maceió, AL, Brazil \\ ${ }^{3}$ Universidade Federal de Alagoas, ICBS/UFAL, Praça Afrânio Jorge s/n, Prado, 57010-020 Maceió, AL, Brazil \\ ${ }^{4}$ Departamento de Morfologia, Cidade Universitária Professor José Aloísio de Campos, Avenida Marechal Rondon, \\ s/n Jardim Rosa Elze, 49100-000 São Cristovão, SE, Brazil
}

Correspondence should be addressed to José Aderval Aragão; jaafelipe@infonet.com.br

Received 21 June 2013; Accepted 12 July 2013

Academic Editors: J. E. Alvernia, C. Kopuz, and T. Yamaguchi

Copyright (c) 2013 Ivan do Nascimento da Silva et al. This is an open access article distributed under the Creative Commons Attribution License, which permits unrestricted use, distribution, and reproduction in any medium, provided the original work is properly cited.

\begin{abstract}
The metopic suture is located between the tubercles of the frontal bone. There are divergences regarding the exact time at which it closes, which ranges from the first to the tenth year of life, although it may persist into adulthood. This study was conducted on 134 dry crania from adult Brazilians, of which 95 were male and 39 were female. These were available in the anatomy laboratories of higher education institutions in Maceió, AL, Brazil. All the crania were examined macroscopically with regard to the presence (metopism: M) on absence of the metopic suture. $\mathrm{M}$ was considered to be complete (Mc) when it continued uninterruptedly from the nasium to the bregma and incomplete (Mi) when it was not present over its entire length. It was observed that Mc was present in $4.48 \%(6 / 134)$ of the skull examined, of which 50\% (3/134) were male and 50\% (3/134) were female. An incomplete metopic suture was found in $5.22 \%(7 / 144)$ of the crania and more frequently among males $(3.73 \% ; 5 / 134)$. Among the crania with a metopic suture, the dolichocephalic type predominated (7.46\%) in relation to brachycephalic crania (1.49\%) and mesocephalic crania $(0.74 \%)$. There was no predominance of metopism between the sexes, while an incomplete metopic suture was slightly more common among males.
\end{abstract}

\section{Introduction}

The frontal bone is a singular, median, and symmetrical bone that occupies the most anterior part of the cranium. It has joints with the parietal, ethmoid, sphenoid, nasal, zygomatic, lacrimal, and maxillary bones, thereby contributing towards uniting the neurocranium and the viscerocranium [1].

During the development stage, the frontal bone is a double bone, with right and left halves that grow together [2] and unite along the median line at the metopic suture [3]. This usually starts to undergo the fusion process at the age of two years [4] and may have completely fused by the age of six years $[2,5]$, eight years $[4,6]$, or ten years [1]. However, in approximately $8 \%$ of adults, the two halves of the frontal bone do not fuse [4], and the metopic suture persists. The suture may be incomplete or complete (when it extends from the nasium to the bregma), and this condition is known as metopism [7-9]. This name originates from the Greek word metopion, which means a space between the eyebrows [10].

Metopism has various degrees of incidence [11]: from $7 \%-8 \%$ among Europeans to $1 \%$ in Africans and $4-5 \%$ in Mongolians. Overall, the range of incidence can go from $1 \%$ to $12 \%$, and it is slightly more prevalent among males [12].

The incidence of metopism and the difference in forms also vary according to geographical region [13]. In Lebanon it was $0.82 \%$ [14], in Nigeria 3.14\% [13], in India 2.66\% [15], in southern India 6.25\% [16], and in Europe 7 to $10 \%[12,17]$.

Prevalence of metopism is important, because, if not, this can be confused with a fracture of the frontal bone or even with a sagittal suture on radiological images $[13,18]$. This is also important in paleodemography and forensic medicine [19]. In the present study, our objective was to determine the rate of occurrence of metopism in dry crania of adult humans. 
TABLE 1: Occurrence of types of metopic suture according to sex.

\begin{tabular}{lcccccc}
\hline \multirow{2}{*}{ Types of metopic suture } & \multicolumn{9}{c}{ Sex } & & \multirow{2}{*}{ Male } & \multicolumn{2}{c}{ Female } & \multicolumn{2}{c}{ Total } \\
& $n$ & $\%$ & $n$ & $\%$ & & \\
\hline Complete (metopism) & 3 & 23.08 & 3 & 23.08 & 6 & 46.15 \\
Incomplete & 5 & 38.46 & 2 & 15.38 & 7 & 53.85 \\
\hline Total & 8 & 61.54 & 5 & 38.46 & 13 & 100.00 \\
\hline
\end{tabular}

\section{Material and Method}

134 dry crania from adult humans ( 95 from males and 39 from females) were analyzed. All of them belonged to anatomy laboratories in higher education institutions in Maceió, AL, and had been obtained in accordance with Law 8501 of November 30, 1992, which deals with use of unclaimed cadavers for teaching and research purposes.

All the crania were macroscopically examined with regard to the presence or absence of the metopic suture. It was considered to be complete when it continued uninterruptedly from the nasium to the bregma and incomplete when it was not present over this entire length.

The crania were also classified according to the cephalic index $(\mathrm{CI})$ as follows: brachycephalic $(\mathrm{CI}>80)$, dolichocephalic $(\mathrm{CI}<80)$, or mesocephalic $(\mathrm{CI}=80)$. This index was calculated by dividing the maximum width, that is, the distance between the euryons (the widest cross-sectional distance from side to side), by the maximum length, that is, the distance between the glabella and the opisthocranion (the glabella is located on the median plane, between the eyebrow arches, and the opisthocranion is the posterior point which is furthest from the longitudinal plane), multiplied by 100 . The measurements of the maximum length and width of the cranium were made using Willis compasses. The crania were classified in accordance with Latarjet and Liard [1].

\section{Results}

Out of the 134 crania examined, the metopic suture was found in $9.7 \%(13 / 134)$ of the cases, of which $61.5 \%(8 / 13)$ were in males and $38.5 \%(5 / 13)$ in females. A complete metopic suture (Figure 1) was found in six cases (46.2\%), while an incomplete suture (Figure 2) was observed in seven cases (53.8\%) (Table 1).

According to the anthropometric characteristics of the crania studied by means of the cephalic index, $47.76 \%$ (64) were of brachycephalic type, $44.03 \%$ (59) were dolichocephalic, and $8.21 \%$ (11) were mesocephalic. However, when we classified the types of cranium according to whether a metopic suture was present, $7.46 \%$ (10) were dolichocephalic, $1.49 \%$ (2) were brachycephalic, and $0.74 \%$ (1) were mesocephalic.

\section{Discussion}

There are divergences in the scientific literature in relation to the exact timing of closure of the metopic suture. Fusion

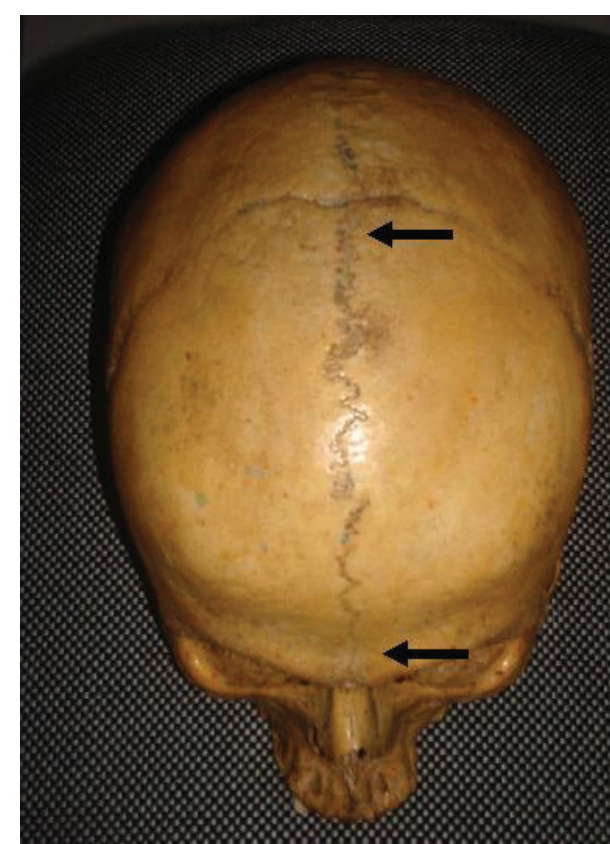

FIGURE 1: Complete metopic suture (arrow).

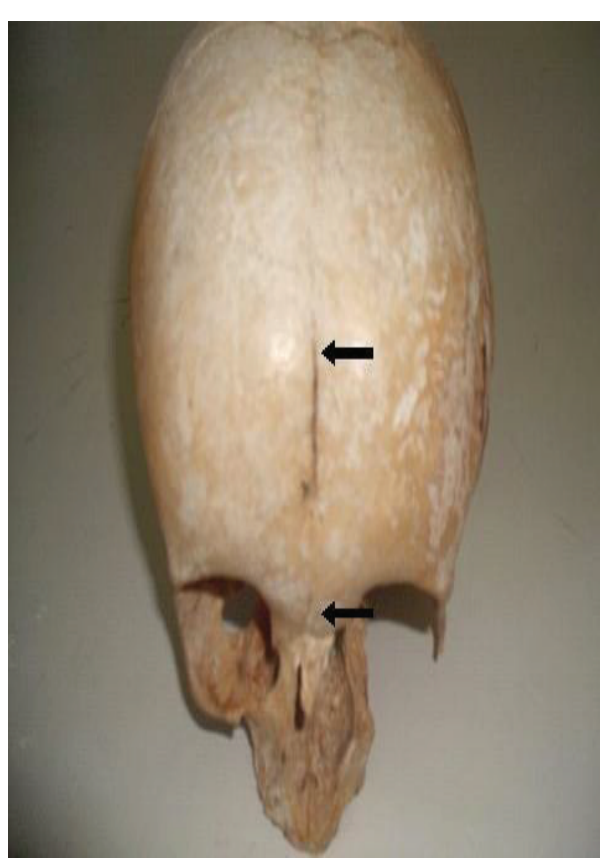

FIGURE 2: Incomplete metopic suture (arrow).

has been reported as occurring between the first year and the beginning of the second year of life [28], before the sixth year [5], in the eighth year $[4,6]$, or in the tenth year [1]. According to Sant'Ana Castilho et al. [28], there are several causes of failure of the metopic suture to fuse, but genetic influence is currently the factor most accepted by the scientific community.

In the present study, metopism was found in $4.48 \%$ of the crania, which was similar to what was found in Indian 
TABLE 2: Incidence of metopism in different ethnic groups, as reported by various authors.

\begin{tabular}{|c|c|c|c|}
\hline Study & Ethnic group & Occurrence (\%) & Year \\
\hline Jit and Shah [20] & Indian (Punjab) & 5 & 1948 \\
\hline Das et al. [21] & Indian (Uttar Pradesh) & 3.31 & 1973 \\
\hline Agarwal et al. [15] & Indian (Kanpur) & 2.66 & 1979 \\
\hline Bryce [22] & $\begin{array}{c}\text { European } \\
\text { Mongolian } \\
\text { Black African } \\
\text { Australian } \\
\text { Scottish }\end{array}$ & $\begin{array}{l}8.70 \\
5.10 \\
1.20 \\
1.00 \\
9.50\end{array}$ & 1917 \\
\hline Keith [23] & Subject to race & $3-8$ & 1948 \\
\hline WOO [24] & $\begin{array}{l}\text { Mongoloid } \\
\text { Negroid }\end{array}$ & $\begin{array}{l}10.0 \\
2.00\end{array}$ & 1949 \\
\hline Frazer and Breathnach [17] & $\begin{array}{c}\text { European } \\
\text { East Asian } \\
\text { African }\end{array}$ & $\begin{array}{c}7-10 \\
4-5 \\
1.00\end{array}$ & 1965 \\
\hline Romanes [25] & European & Up to 8.00 & 1972 \\
\hline Berry [26] & Various ethnic groups & 7.40 & 1975 \\
\hline Ajmani et al. [13] & Nigerian & $3-4$ & 1983 \\
\hline Chandrasekaran and Shastri [27] & Indian (southern India) & 5.00 & 2012 \\
\hline Present study & Brazilian (Maceió) & 4.48 & 2013 \\
\hline
\end{tabular}

populations (Punjab, Uttar Pradesh, and southern India), Mongolians, East Asians, and Nigerians (3.31 to 5.1\%) but was lower than what was found among Scots, Mongoloids, and Europeans (7\% to $10 \%)$ (Table 2).

A study conducted in Brazil by del Sol et al. [18] on 400 crania at the São Paulo Medical School (Escola Paulista de Medicina), Federal University of São Paulo, reported that the incidence of metopism was $2.75 \%$. However, in an analysis on 71 crania at Paranaense University, Sant'Ana Castilho et al. [28] found an incidence of $7 \%$. In the present study, out of the 134 crania found in anatomy laboratories in higher education institutions in Maceió, AL, the rate of occurrence of metopism was $4.48 \%$ and suture metopic $9.7 \%$. This rate was higher than that found by either of the previous Brazilian studies.

Among the 13 crania in which a metopic suture was seen to be present, the rate of occurrence was greater among males (61.54\%), which corroborates the findings from studies by Skrzat et al. [12], Murlimanju et al. [29], and van der Meulen [30], in which there was also greater occurrence among males. However, this was contrary to the findings of Sant'Ana Castilho et al. [28], who observed that $80 \%$ of the occurrences of metopic suture were in females. According to Baaten et al. [14] the rates of occurrence were similar among males and females.

However, when we correlated occurrences of metopic suture with the type of cranium, according to the cephalic index, we found that the occurrences in the dolichocephalic type were much greater than in the brachycephalic type. This differed from the findings of Sant'Ana Castilho et al. [28], who reported greater occurrence in the brachycephalic type. On the other hand, according to Bryce [31], what exists in reality are equal occurrences between the dolichocephalic and brachycephalic cranial types.

\section{Conclusion}

The rate of occurrence of metopism in dry crania in the city of Maceió was $4.48 \%$, without predominance in one sex over the other. Incomplete metopic sutures were observed in $5.22 \%$ of the crania, with slight predominance among males.

Knowledge of the possible presence of metopism serves to alert imaging professionals to the fact that this is just a variation and does not imply any harm to the population's health. Moreover, this variation should not be confused with a line of fractures in the frontal bone, especially if observed close to the median line.

\section{References}

[1] M. Latarjet and A. R. Liard, "Cabeça," in Anatomiahumana, M. Latariet and A. R. Liard, Eds., pp. 69-71, Panamericana, São Paulo, Brasil, 2nd edition, 1993.

[2] Van der Graaff, "Introdução e esqueleto axial," in Anatomia Humana, Van der Graaff, Ed., pp. 131-171, Manole, São Paulo, Brasil, 6th edition, 2003.

[3] J. G. Dangelo and C. A. Fattini, "Crânio, coluna vertebral e partes moles do dorso," in Anatomia Humana Sistêmica E Segmentar Para Estudantes De Medicina, J. G. Dangelo and C. A. Fattini, Eds., pp. 357-390, Atheneu, São Paulo, Brasil, 2nd edition, 1998.

[4] K. L. Moore and A. F. Dalley, "Cabeça," in Anatomia Orientada Para A Clínica, K. L. Moore and A. F. Dalley, Eds., pp. 821-864, Guanabara Koogan, Rio de Janeiro, Brasil, 4th edition, 2007. 
[5] G. J. Tortora, “O Sistema esquelético: o esqueleto axial," in Corpo Humano: Fundamentos de Anatomia e Fisiologia, G. J. Tortora, Ed., pp. 175-207, Guanabara Koogan, Rio de Janeiro, Brasil, 9th edition, 2002.

[6] C. M. Gross, “Osteologia," in Anatomia, C. M. Gross, Ed., pp. 80-233, Guanabara Koogan, Rio de Janeiro, Brasil, 29th edition, 1977.

[7] E. Gardener, D. J. Gray, and R. O’Rahilly, "Crânio e osso hióide," in Anatomia. Estudo Regional do Corpo, E. Gardener, D. J. Gray, and R. O’Rahilly, Eds., pp. 541-569, Guanabara Koogan, Rio de Janeiro, Brasil, 4th edition, 1988.

[8] A. K. Bilodi, B. K. Agrawal, S. Mane, and A. Kumar, "A study of metopic sutures in human skulls," Kathmandu University Medical Journal, vol. 2, no. 2, pp. 96-99, 2004.

[9] G. Bademci, T. Kendi, and F. Agalar, "Persistent metopic suture can mimic the skull fractures in the emergency setting?" Neurocirugia, vol. 18, no. 3, pp. 238-240, 2007.

[10] G. J. M. Fernandes, "Eponímia: glossário de termos epônimos em Anatomia," in Etimologia: Dicionário Etimológico da Nomenclatura Anatômica, Plêiade, São Paulo, Brasil, 1999.

[11] S. Eroğlu, "The frequency of metopism in anatolian populations dated from the neolithic to the first quarter of the 20th century," Clinical Anatomy, vol. 21, no. 6, pp. 471-478, 2008.

[12] J. Skrzat, J. Walocha, and J. Zawiliński, "A note on the morphology of the metopic suture in the human skull," Folia Morphologica, vol. 63, no. 4, pp. 481-484, 2004.

[13] M. L. Ajmani, R. K. Mittal, and S. P. Jain, "Incidence of the metopic suture in adult Nigerian skulls," Journal of Anatomy, vol. 137, no. 1, pp. 177-183, 1983.

[14] P. J. J. Baaten, M. Haddad, K. Abi-Nader, A. Abi-Ghosn, A. Al-Kutoubi, and A. R. Jurjus, "Incidence of metopism in the Lebanese population," Clinical Anatomy, vol. 16, no. 2, pp. 148151, 2003.

[15] S. K. Agarwal, V. K. Malhotra, and S. P. Tewari, "Incidence of the metopic suture in adult Indian crania," Acta Anatomica, vol. 105, no. 4, pp. 469-474, 1979.

[16] K. K. Chakravarthi and N. Venumadhav, "Morphological study of metopic suture in adult South Indian skulls," International Journal of Medical and Health Science, vol. 1, no. 2, pp. 23-28, 2012.

[17] J. E. S. Frazer and A. S. Breathnach, Frazer's Anatomy of the Human Skeleton, Churchill Ltda, London, UK, 6th edition, 1965.

[18] M. del Sol, O. Binvignat, P. D. Bolini, and J. C. Prates, "Metopism in Brazilians," Revista Paulista de Medicina, vol. 107, no. 2, pp. 105-107, 1989.

[19] G. Hauser, G. Manzi, A. Vienna, and G. F. De Stefano, "Size and shape of human cranial sutures-a new scoring method," American Journal of Anatomy, vol. 190, no. 3, pp. 231-244, 1991.

[20] I. Jit and M. A. Shah, "Incidence of frontal or metopic suture amongst Punjabi adults," Indian Medical Gazette, vol. 83, pp. 507-508, 1948.

[21] A. C. Das, R. C. Saxena, and M. A. Q. Beg, "Incidence of metopic suture in U.P. subjects," Journal of the Anatomical Society of India, vol. 22, article 140, 1973.

[22] T. H. Bryce, "Observations on Metopism," Journal of Anatomy, vol. 51, part 2, pp. 153-166, 1917.

[23] A. Keith, Human Embryology and Morphology, Edward Arnold, London, UK, 6th edition, 1948.

[24] J. K. WOO, "Racial and sexual differences in the frontal curvature and its relation," American Journal of Physical Anthropology, vol. 7, no. 2, pp. 215-226, 1949.
[25] G. J. Romanes, Cunningham's Textbook of Anatomy, Oxford University Press, London, UK, 11th edition, 1972.

[26] A. C. Berry, "Factors affecting the incidence of non metrical skeletal variants," Journal of Anatomy, vol. 120, part 3, pp. 519535, 1975.

[27] S. Chandrasekaran and D. Shastri, "A study on metopic suture in adult south Indian skulls," International Journal Of Basic Medical Sciences, vol. 1, no. 7, pp. 379-382, 2012.

[28] M. A. Sant'Ana Castilho, J. Y. Oda, and D. D. M. Gonçales Sant'Ana, "Metopism in adult skulls from Southern Brazil," International Journal of Morphology, vol. 24, no. 1, pp. 61-66, 2006.

[29] B. V. Murlimanju, L. V. Prabhu, M. M. Pai, A. A. Goveas, K. V. N. Dhananjaya, and M. S. Somesh, "Median frontal suturesincidence, morphology and their surgical, radiological importance," Turkish Neurosurgery, vol. 21, no. 4, pp. 489-493, 2011.

[30] J. van der Meulen, "Metopic synostosis," Child's Nervous System, vol. 28, no. 9, pp. 1359-1367, 2012.

[31] T. H. Bryce, "Osteology and arthrology," in Quain's Elements of Anatomy, T. H. Bryce, Ed., p. 177, Longmans Green, London, UK, 11th edition, 1915. 

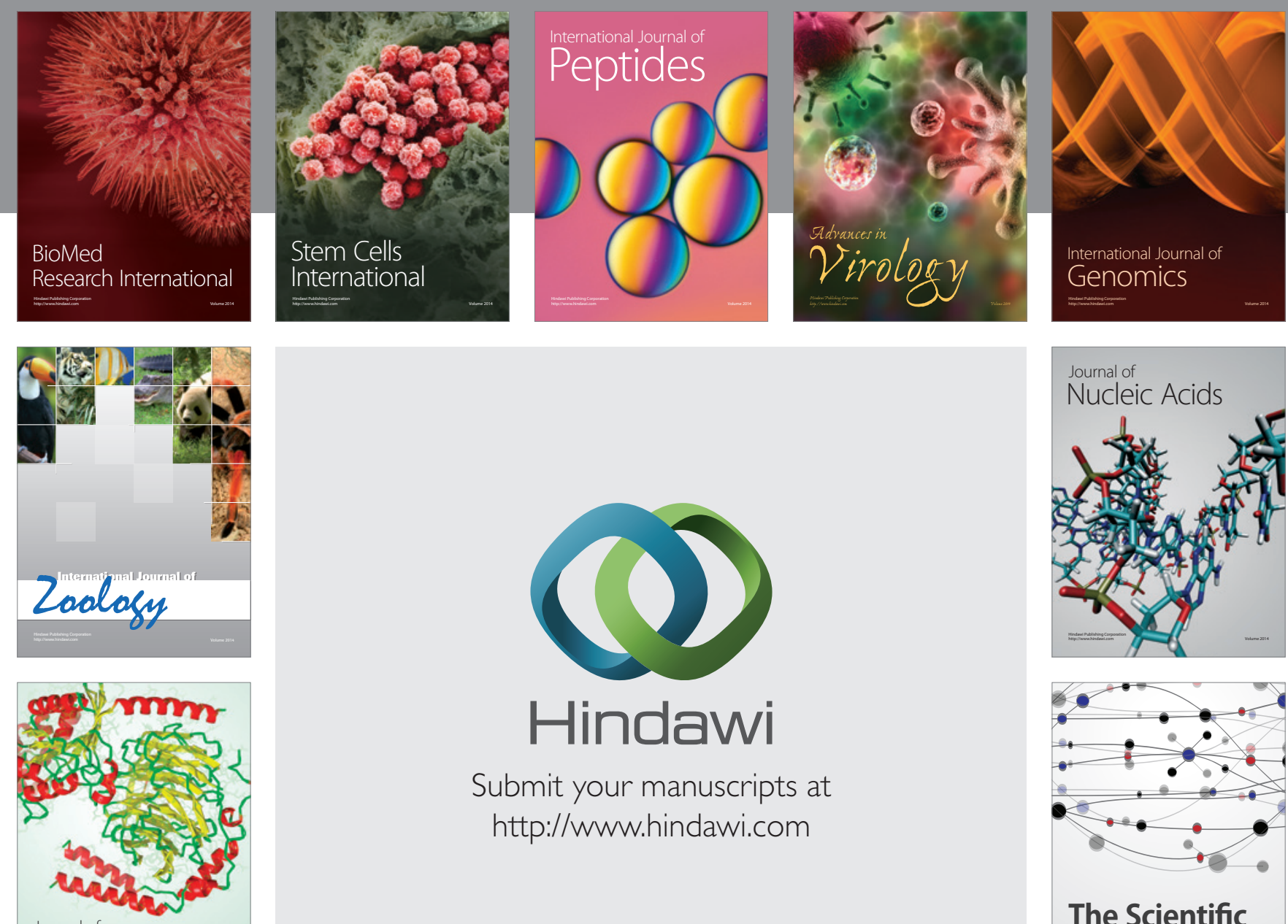

Submit your manuscripts at

http://www.hindawi.com

Journal of
Signal Transduction
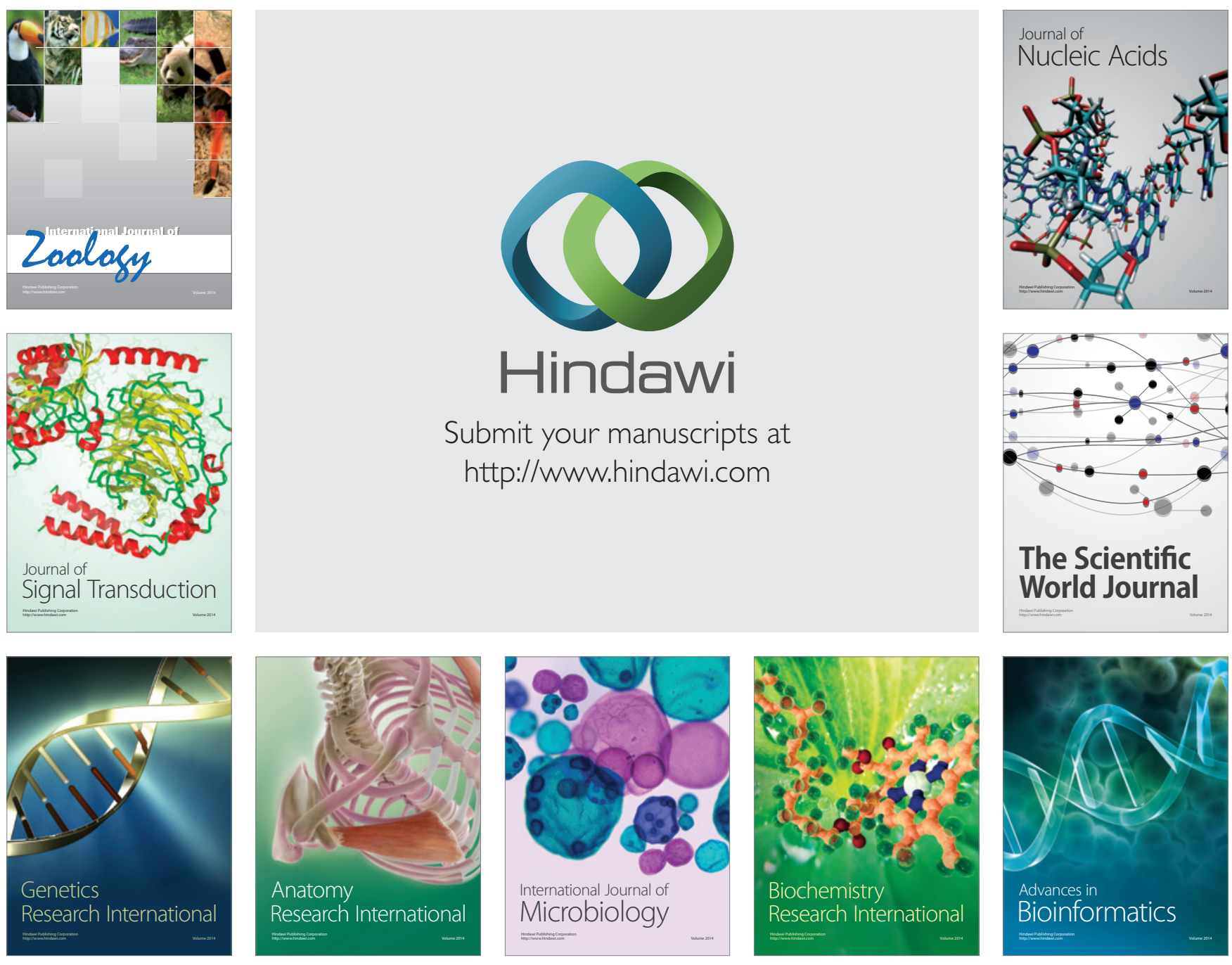

The Scientific World Journal
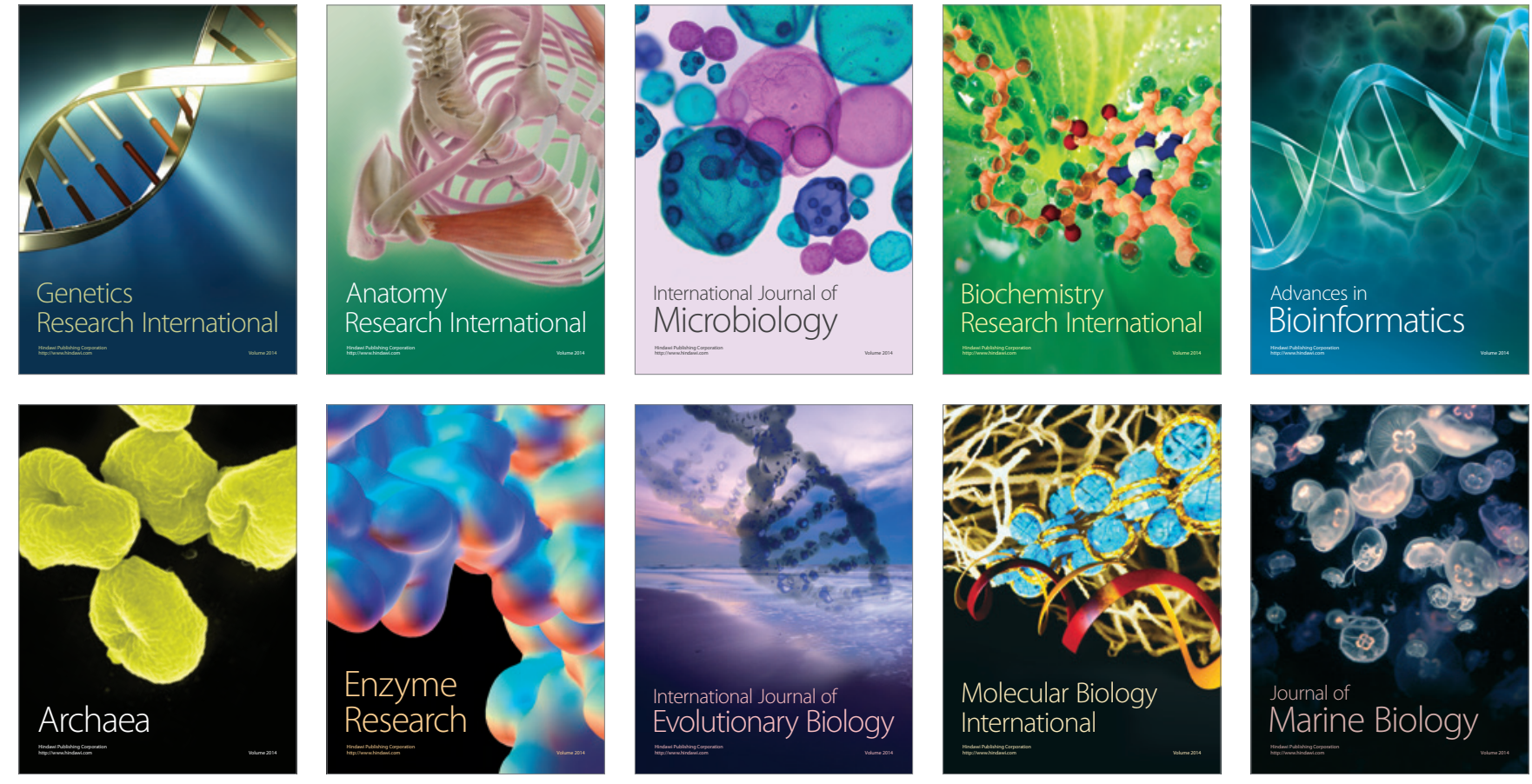